\title{
A Fortune in Fruit: Nicholas Longworth and Grape Speculation in Antebellum Ohio
}

\section{Erica Hannickel}

Nicholas Longworth (1782-1863), the "father of American wine"-more accurately, father of the first commercially successful American champagne- has been lauded as the harbinger of an ideal democratic agrarian republic. ${ }^{1}$ In his 1858 portrait, Longworth, also known as the "Western Bacchus," stands among the things that brought him wealth: hundreds of acres of land receding in the background, and his grapes (see Figure 1). ${ }^{2}$ Viticulturists had known for decades that the most popular European winegrapes (Vitis vinifera like Cabernet Sauvignon and Chardonnay) would not grow well in North America under normal circumstances. The cultural importance of finding a native American wine, as well as improving the quality and taste of America's antebellum vinous productions, are at the heart of Longworth's accepted honorific life story.

In this celebratory vein, fruit speculators, although quite common in the nineteenth century throughout all regions, have not undergone the same scrutiny as the typical litany of traders, capitalists, and real estate men who populate the story of U.S. territorial and market expansion. ${ }^{3}$ Many fruit growers across the region did more than just grow fruit. As speculators, they sought to capitalize on their fruit as well as the resale of the "improved" land the fruit grew upon and the margin of profit that could be added by employed labor. Specifically, behind the Longworth horticultural egalitarian myth is a story of wealth made through land speculation and, crucially, decades of labor exploitation that has been obscured by the democratic mythos of American fruit production and fruit tourism. 


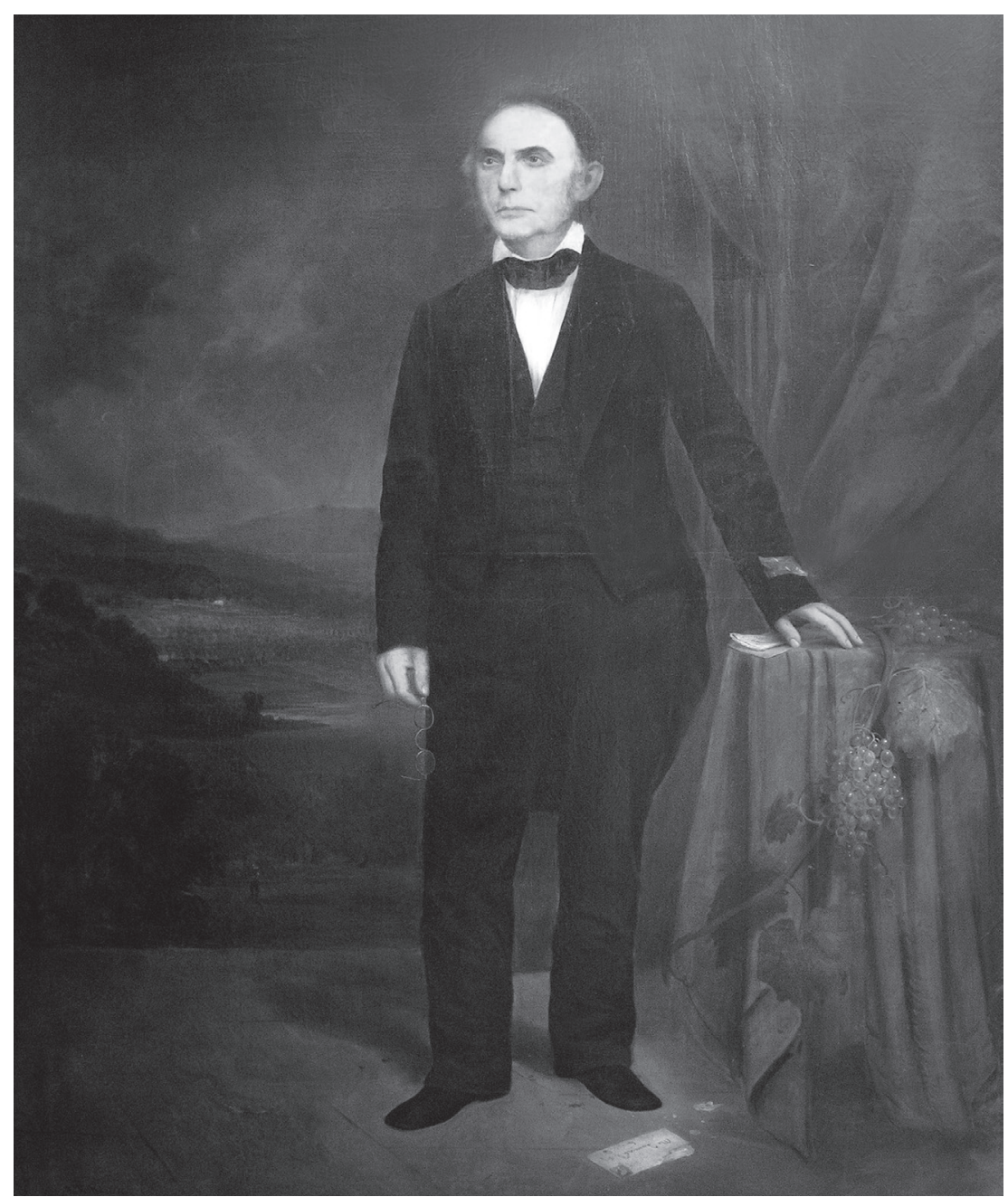

Figure 1: Robert Duncanson, Portrait of Nicholas Longworth, 1858, oil on canvas. Collection of the University of Cincinnati. Photo courtesy of the Taft Museum of Art.

Nineteenth-century pomology (the art of growing fruit) provided an excusable, even commendable, framework for turning public property into private property and for hiding any questionably exploitative dealings in the shade of its fruitful bowers. Claiming a kind of passive, utilitarian, scientific, and benevolent role in the landscape and society, viticulture and fruit growing functioned to deny the realities of land speculation, agricultural imperialism, and the exploitation of labor that were key ingredients of the business as it was practiced in the Cincinnati area. ${ }^{4}$ 
At one time the second-wealthiest man in the United States, "Old Nick" should take a more prominent place within the history of the market revolution and early capitalist development of western agriculture. The multimillionaire viticulturist modeled an early type of capital accumulation previously thought to have begun in California decades later, and he did it in antebellum Ohio, no less. Ohio, in this regard, also deserves a more prominent place in the history of fruit- and grape-growing, alongside the better-known pomological loci of New York and California. ${ }^{5}$

\section{Dreaming a larger vineland in Ohio}

Early- to mid-century Ohio has a unique place in the history of the Old Northwest, although it was a part of the larger market transformation happening throughout the antebellum West and upper South. National policies distributed land to farmers and encouraged farm expansion from east to west, achieving the goal of nation building through settlement by white migrants. ${ }^{6}$ In 1803, military lands were opened for sale in Ohio; before 1814, pioneers could also use squatters' laws to claim land. Through mid-century, investors leased school and military lands very cheaply, for terms as long as ninety-nine years. The Homestead Act of 1841 further opened lands in the Midwest to sale and farming. ${ }^{7}$ The Ohio River, in addition to its utility in commerce, developed as a symbolic boundary between freedom and slavery. As "far western country," a kind of first stop "across the mountains," Ohio was an ideological boundary, yet also an artery, linking the nation east to west and north to south. ${ }^{8}$

Popular opinion held that one major city would eventually dominate the interior of the continent, and Cincinnati emerged as the early regional leader. ${ }^{9}$ In his 1851 popular guidebook and who's-who list for the city (reprinted every few years for decades), Charles Cist, an early booster, linked "Cincinnati-Its Destiny" with "[t]he law of gravitation or centralization ... known to be one of the laws of nature":

New York had been made so before ... [but] Cincinnati is the grand centre of the United States, not geographically, perhaps, but the centre of the forces and influences, which, when readjusted after the introduction of the great disturbing cause, the railroad, must settle and determine the destiny and relative position of various cities or centres, which are now struggling for supreme ascendancy on this continent. ${ }^{10}$

Cist's hyperbole was not entirely unfounded. In 1820 the city was nearly twice as large as its nearest Midwestern competitor (St. Louis), and it increased that margin throughout the 1840s. With river commerce development in the $1830 \mathrm{~s}$, Cincinnati became the most diversified metropolis west of the Alleghenies; in the same decade, it grew from a few hundred residents to 50,000 people and 
to more than a mile in radius. The city thus became the spearhead of the midcentury capitalist frontier. Like many other cities at the time, Cincinnati often boasted that it had a central riverine, "strategic" and "beautiful" setting — but the "Queen City" was able to make good on its boasts for at least two decades. ${ }^{11}$ Cist's boosterism invokes the competitiveness that guided city building in this period: he believed that the city's success through transportation and trade happened at the expense of its rivals. ${ }^{12}$

In addition to its importance in the river trade, Cincinnati experienced a remarkable cultural flowering in the three decades before the Civil War, when it was known as the singular "literary emporium of the West." ${ }^{13}$ Due in large part to Longworth's patronage, many fine arts and hundreds of cultural clubs emerged in Cincinnati. Longworth's interest and funds propelled many significant artists' careers, including that of sculptor Hiram Powers, as well as that of Longworth's portraitist, African-American Hudson River School painter Robert Duncanson (see Figure 1). A cultural self-awareness grew in this new space that identified as "not-East" as well as "not-South," as Cincinnatians wanted their city to be "living proof that civilization and refinement could flourish in the former wilderness." ${ }^{14}$

Cincinnati's civilization and refinement were to be demonstrated in part through expert local wine production. New York agricultural journals such as The Horticulturist had for years called for further cultivation of the "far western lands" of the Ohio Valley. ${ }^{15}$ High-profile New York horticulturists Andrew Jackson Downing and William Prince, who sustained the popular construction of country gentlemen in their horticultural publications and nursery businesses, projected a neo-yeoman dream into the Ohio Valley by repeatedly encouraging viticulturists to move West and for the government to sponsor grape growing experimentation there. In an anonymous 1848 report in Downing's Horticulturist on "The Vineyards of Ohio," the civilizing of the frontier is read through the domestication of grapevines:

If we take a retrospective glance of fifty or sixty years ... when the unexplored wilds of Ohio- the now indeed beautiful Ohio - were penetrated by a few hardy adventurers ... encountering at every step the shrieks of wild beasts, and their little but less ferocious companion, the Red Man. . . . The great abundance of the wild grape, found indigenous in the forest, and the luxuriancy of their growth, towering and spreading over the tops of the tallest trees, abundantly loaded with fruit, justifies the idea that the better and finer sorts will flourish here also. ${ }^{16}$

The author links grape growing with natural abundance and a northern AngloAmerican pastoral ideal: nature was already a vineyard in Ohio. This narrativeof an America that had once been lush with greenery but was now truly beautiful because of the vineyards spreading through the Ohio Valley and beyond - was 
popular in the mid-nineteenth century. It revealed a continuing belief in fruit and garden cultivation as a key to civilization and the nation's future. Other manifest destiny narratives with viticultural overlays are apparent in the full text: that the land was wild and filled with savage men waiting to be tamed and taught a proper way of life; that the abundant agricultural riches were a gift from God for those with the moral and technical means to develop them; and that destiny was involved from the moment the first white foot was planted on American soil. "Wild" and "indigenous," as well as "better and finer" varietals could be enhanced and made better able to produce the classic drink of civilization. The potency and "luxuriancy" of vines in their natural state would naturally be brought to their full potential when under the influence of commerce and social mores. This vinous vision of manifest destiny was especially important for a culture that needed to make the case that just as the nation should easily spread everywhere across North America, so should its number-one claim to refinement and bourgeois culture: wine. ${ }^{17}$

The Ohioan vision of cultural and national prominence through viticulture was also spread via horticulturists' contextualized appropriation of a Biblical parable from 1 Kings 4:25. The Horticulturist and Ohio Cultivator both published an article detailing progress in "the vineyards of the West":

To sit under our own vine and fig tree, with no one to make us afraid, is the most ancient and sacred idea of a life of security, contentment and peace. In a national sense, we think we may begin to lay claim to this species of comfort ... there is no longer any doubt regarding the fact that the valley of the Ohio, with its vine-clad hills, will soon afford a resting place for millions of cultivators, who may sit down beneath the shadow of their own vines, with none to make them afraid. ${ }^{18}$

"Under one's own vine and fig tree," a Biblical allusion to individual peace and prosperity, is here re-envisioned "in a national sense" for cultivators in the Ohio Valley. It becomes a statement about nationalist dominion over the land, its pacific tone a paradoxical call to arms against those who would "make them afraid," namely the removed American Indians - and the reigning European wine producers. Beyond wine's traditional place in religious historiography and temperance movements, the Horticulturist and Ohio Cultivator helped install Ohio grape culture within the racialized nationalism that shaped so many expansionist frontier narratives.

Cincinnati was placed at the center of the West's pomological manifest destiny because in addition to its "strategic" setting and cultural prominence, it was the largest and most productive wine region in the nation for three decades around the Civil War. Regional growers sought to share knowledge and capitalize on their collective prestige by organizing the Cincinnati Horticultural Society. Founded in 1843 by local businessmen-growers, the society was an active group 
of urban boosters, several of whom were also leading winemakers (see Figure 2). In the society's founding portrait, members gather around their edible riches. Grapes are draped upon and around all other fruit at the table, illustrating the society's investment in viticulture. With weekly meetings, "correspondence with distinguished horticulturalists in different parts of the Union," and semi-annual flower and fruit exhibitions, membership swelled to 700 by 1851 and to almost 900 in $1859 .{ }^{19}$

Under the Society's guidance, winemaking flourished. A period of major expansion of the Cincinnati wine industry marked the decades after 1842, the year in which Longworth stumbled onto his formula for "sparkling Catawba," a much more palatable and popular beverage than his previous "Cincinnati hock." In 1845, one of the Society's charter members, Melzer Flagg (also Longworth's employee and son-in-law) collected statistics on vineyards in Hamilton County, supporting Cincinnati's braggadocio with geographical data. He found that 83 vineyards covered 250 acres in the Cincinnati area, producing 23,000 gallons of wine per annum. ${ }^{20}$ Five years later, the Society increased its statistical scope to include any vineyard within twenty miles of the city, reflecting the Cincinnati region's growing dominance as a national wine region. It found 750 acres of grapevines being tended, two-thirds of which were bearing fruit. ${ }^{21}$ By 1852 , the acreage had increased to 1,200 acres, and more than 600 people were employed in winemaking. ${ }^{22}$ In 1853, the region's vintners produced 450,000 bottles of wine, and Cincinnati's title as the "Rhine of America" had finally taken hold in the national discourse about U.S. wine. DeBow's Review described:

Cincinnati is the centre of the wine region in the Ohio valley, and the Ohio river has not inaptly been called the "Rhine of America." ... The "vine-clad hills" already afford a pleasing variety in the scenery around this city, and the vintage is anticipated with interest and solicitude. It is a new feature in the harvest of this rich valley, and a product that must before long form an important branch of our national industry. ${ }^{23}$

Cincinnati wine was clearly ascendant. In 1855 , the viticultural area again grew to 1,500 acres, and these vineyards made up more than two-thirds of the total fruit acreage in the Ohio Valley. Near the end of the decade, 35 percent of the nation's total winecrop came from the Cincinnati region, nearly double the percentage of the next most productive state, California. Some Cincinnati growers posted 40-percent profits by the mid-1850s. ${ }^{24}$ The "Rhine of America" enjoyed its title and stature in fruit experimentation and production for more than twenty years, illustrating and crowning Cincinnati's claim to being the "Queen City" of the Great West.

In addition to profit, a chief focus of grape growing in these years was experimentation with new varietals. Dozens of articles about new native and hybrid grapes were published each month in national journals. A partial list of 


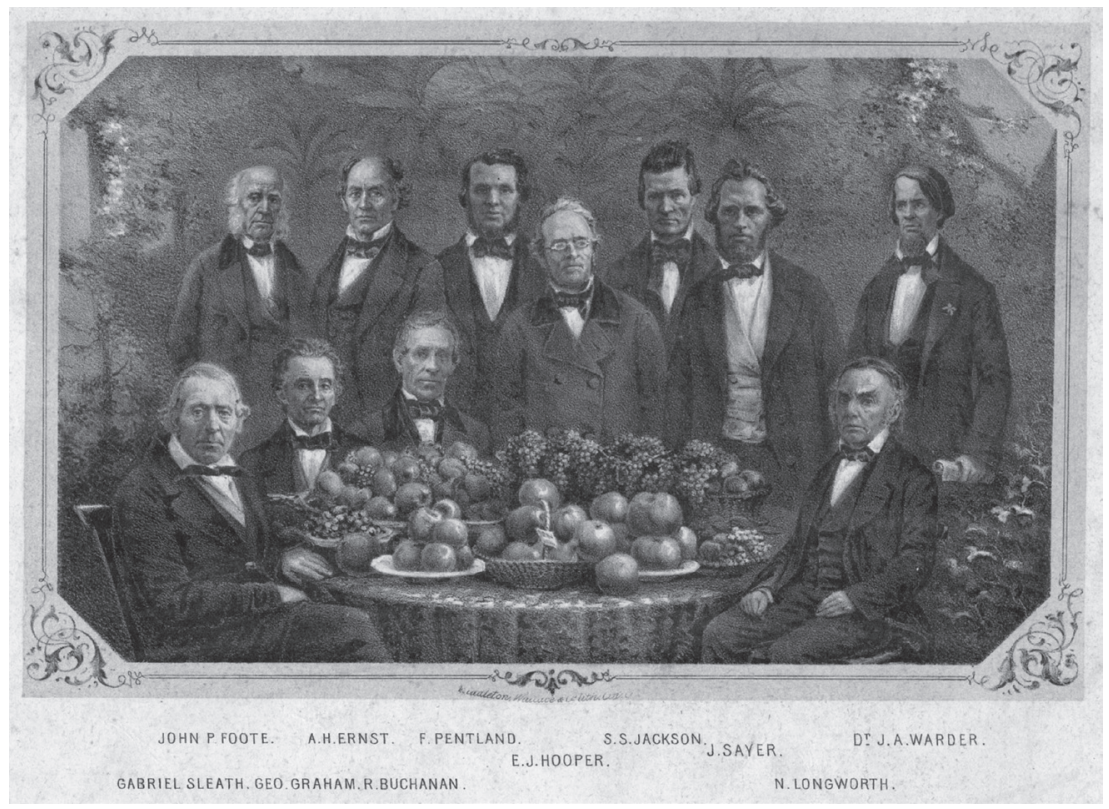

Figure 2: Cincinnati Horticultural Society, 1843. Courtesy Cincinnati Historical Society.

"grapes raised and exhibited" by Nicholas Longworth in 1846 contained over twenty types. ${ }^{25}$ Because of his wealth and the national reputation he gained due to his successful grape experiments, Longworth (seated at the bottom right in Figure 2) was the Cincinnati Horticultural Society's preeminent member. His leadership in and enthusiasm for the local grape trade, not to mention his bottomless pockets and many land investments, exemplified the Society's ideals of agricultural beauty and industry through viticulture in Cincinnati into the 1860s.

\section{Longworth, Entrepreneur of Fruit}

Longworth's recorded life story is a classic rags-to-riches tale of an evenkeeled, immensely hard-working, odd, and lucky frontier immigrant. Longworth came to Cincinnati from Newark, New Jersey in 1803, at the age of $21 .^{26}$ According to several early biographers, he was an impoverished but plucky lawyer, running away from an embarrassing family history-his parents had been Loyalists, and their estate had been ruined after the Revolution. In his first case in Cincinnati, defending an accused horse thief, Longworth reportedly received in payment two copper stills full of hard alcohol. With a keen early American capitalist's foresight, he immediately traded the appliances and liquor to a bartender for 33 acres of land on the town's outskirts. And in a typically mythic leap, most stories conclude that "by 1830 his lot was in the heart of the business 
district, and Longworth was one of the richest men in America." ${ }^{27}$ According to the brief celebratory biographies, Longworth traded liquor stills for real estate assets that ultimately made him a multimillionaire. Although the stories focus on Longworth's temperance and pluck, the real estate points to the useful kernel of meaning in the Longworth myth. Once planted with grapevines, the lands around Cincinnati produced the drink of an aspiring, landed middle class. The grapes "tamed" and beautified the outlying lands and signaled permanent, cultured residence. ${ }^{28}$ This foundational story of the first magnate of the West, as well as of the River City, which was then developing as a regional center for trade and several agricultural goods, served not only as a means of temperance-driven moral suasion (the monetary and moral benefits of wine over the stupidity and easy losses of hard alcohol) but also as a story of Ohio's founding and promise as a nationally important place of cultivation and urban sophistication.

Beyond the myth, the years between Longworth's supposed sale of stills and his rise to wealth reveal much more than pluck and luck. Having horticultural interests all his life, he experimented with grape growing beginning in 1813 but was not devoted to it until 1820. (He received his first vines from the Swiss colony in Vevey, Indiana, an earlier small-scale, but successful, wine enterprise. ${ }^{29}$ ) By 1820 , Longworth was successfully growing several types of grapes in vineyards just out of town, and in 1823 he received the Catawba grape from friend (and renowned American viticulturist and handbook author) Major John Adlum. In this way, his riches in real estate were accompanied by, if not in part driven by, his interest and promotion of the grape trade. Longworth was a millionaire by 1825 , and gave up his law practice three years later. ${ }^{30}$

Longworth's grape growing developed during these years from a tinkering interest to a serious investment of his surplus wealth. Like many real estate speculators in the period, he didn't sit on one property, but was acquiring and selling dozens in any given year. The speculator's tactic, one accurate piece of the Longworth myth, was simply to buy up all the land he could, as fast as he could. The 1838 Cincinnati Tax List details over 100 properties that Longworth owned, evaluated at over $\$ 115,000$. This included land solely within the city limits, as well as only the land's assessed value, generally thought to be lower than the market price. ${ }^{31}$

Longworth knew that vineyards had a way of making previously unusable land profitable. No matter how "worthless" the land, or remote from the center of town, Longworth would buy it and begin planting vines. ${ }^{32}$ Especially surprising at the time, Longworth bought up hilly land (much of what was available in southern Ohio). Hills and valleys were thought to be beneficial when growing grapes, as opposed to the flat landscapes necessitated by so many other crops. Longworth's vineyards thus made previously "useless" land pay first through its production of grapes, and second through its sale to speculators and urban developers. As Cincinnati grew, the city and private buyers bought back Longworth's land, then covered with vineyards, for urban development. New York socialist muckraker of the early twentieth century, Gustavus Myers, decried Longworth's 
"land fortune": "The growth [Cincinnati] kept on increasingly. His land lay in the very center of the expanding city, in the busiest part of the business section and in the best portion of the residential districts." Longworth's land sales were the source of most of his wealth; by 1850, his original 33 acres was worth an estimated $\$ 2$ million..$^{33}$

Although not his primary source of wealth, Longworth's profit from his vineyards was significant. By 1844, Longworth had 91 acres of vineyards, yielding 20,000 gallons of wine annually. ${ }^{34}$ By the mid-1850s, he produced 100,000 bottles annually and advertised nationally. Viticulture for Longworth was no longer just a gentleman's pleasurable pursuit. In 1852, his wine was worth $\$ 64,000{ }^{35}$ Longworth's success was repeated throughout the region - by 1859 , there were 3,000 acres of vineyards between Cincinnati and Ripley (forty miles upstream), and those vineyards produced 570,000 gallons of wine annually. ${ }^{36}$

Longworth popularized his wine by encouraging tourism in his picturesque vineyards. After several less-than-profitable early attempts to sell wine, he created tourist sites in his country vineyards 300 feet above the city, a tasting "Wine Garden," and a "wine house" in the middle of downtown. Articles about and romanticized illustrations of Longworth's vineyards ran in Harper's Weekly (see Figure 3) and other national magazines in the 1850s. The illustrations include images of old-world vinetenders and their skilled handiwork juxtaposed against, yet in civilized comfort with, the modern technological advances of the railroad and steamboat. Part of Longworth's vineyards' allure and popularity lay in their proximity to the city, an aspect highlighted in Cincinnati tourist literature and included in Longworth's Wine House, a promotional pamphlet published in the 1860s. In a picture from his tourist literature (see Figure 4), a blissful scene unfolds as rows of vines nestle into the gently curving river below. Longworth's vineyards lay in an inviting "semi-circular arc that enclosed [Cincinnati's] natural amphitheater for twelve miles in circumference. ${ }^{" 37} \mathrm{~A}$ vineyard tour offered not only a leisurely stroll among the vines, but also an elevated perspective on the growing city and region. Longworth's most prominent vineyards were quickly established as premier tourist attractions in antebellum Cincinnati. His house is described in Harper's Weekly:

... a plain but capacious and home-looking building, and its fine locality and beautiful garden and surrounding grounds render it the most popularly attractive spot in the city. As "Mr. Longworth's Garden," it is known throughout the Western country; and it is freely used, by citizens and strangers, as a place of visit and promenade. In it are several fine conservatories, well filled with exotic and rare plants, a grapehouse for foreign vines, and an experimental forcing house. ${ }^{38}$

Vineyard tourism added value to Longworth's real estate, and the views it offered solidified Cincinnati's status as a burgeoning empire city. Visitors to Longworth's 


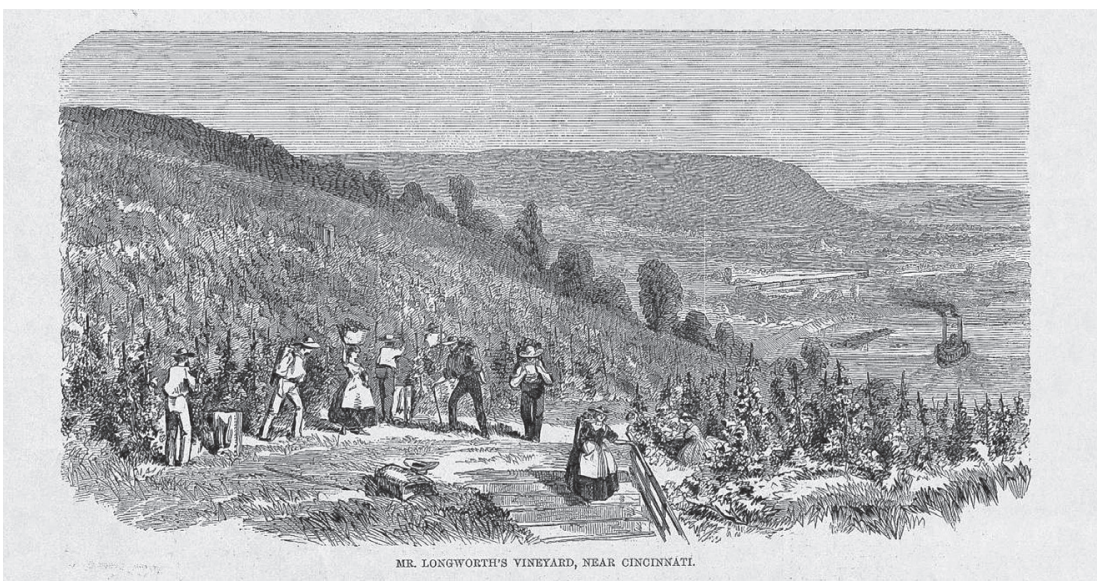

Figure 3: "Mr. Longworth's vineyard, near Cincinnati." Harper's Weekly, July 24, 1858. Courtesy Harpweek.

vineyards and home could thus experience the best of old and new civilizations in a still-natural setting.

The illustrations of Longworth's vineyards reinforce a distinction between other agricultural crops (even other specialty fruit crops) and grapes, when placed on a scale of perceived "naturalness" in a landscape. Very often, vineyards were planted among stumps of felled trees left in the ground. Stumps often figure as signs of progress in nineteenth-century visual art-progress both necessary and violent. But in Figure 4, in the foreground and amidst the vines, stumps are not so much a scar as a naturalized part of the landscape, softened by their placement within the process of making an ostensibly unalienated commodity ${ }^{39} \mathrm{In}$ these images, the vineyard keeps its neo-yeoman, "natural" feel-it is nature, but nature cleaned up, straightened out, made productive and civilized.

The illustrations of Longworth's vineyards also include romanticized labor as part of the classic representation of the vineyard-yet the labor depicted here elides its real local conditions. In the classic vision of the vineyard, work was done by the owners: skilled, middle-class, white hands. But contrary to the blissful, rather Mediterranean pictures here, Longworth utilized poorly-paid tenants - ethnically "other" German immigrants - throughout his wine business. The images, in promoting tourism and an ideal mythos of the vineyard, also functioned to erase his dependence on German labor.

Fully considered, in this way Longworth's life story differs dramatically from recent "democratic," celebratory accounts. As part of his self-crafted democratic and yeoman identity, Longworth always propounded a do-it-yourself ethic: "the cultivation of the grape for wine will be profitable where persons do their own work. It is seldom that any farming pays well where there is much hiring of hands." ${ }^{40}$ This view of labor in the vineyard was in line with a perennial myth of wine production. Wine had long been prized by drinkers for being the essence of 


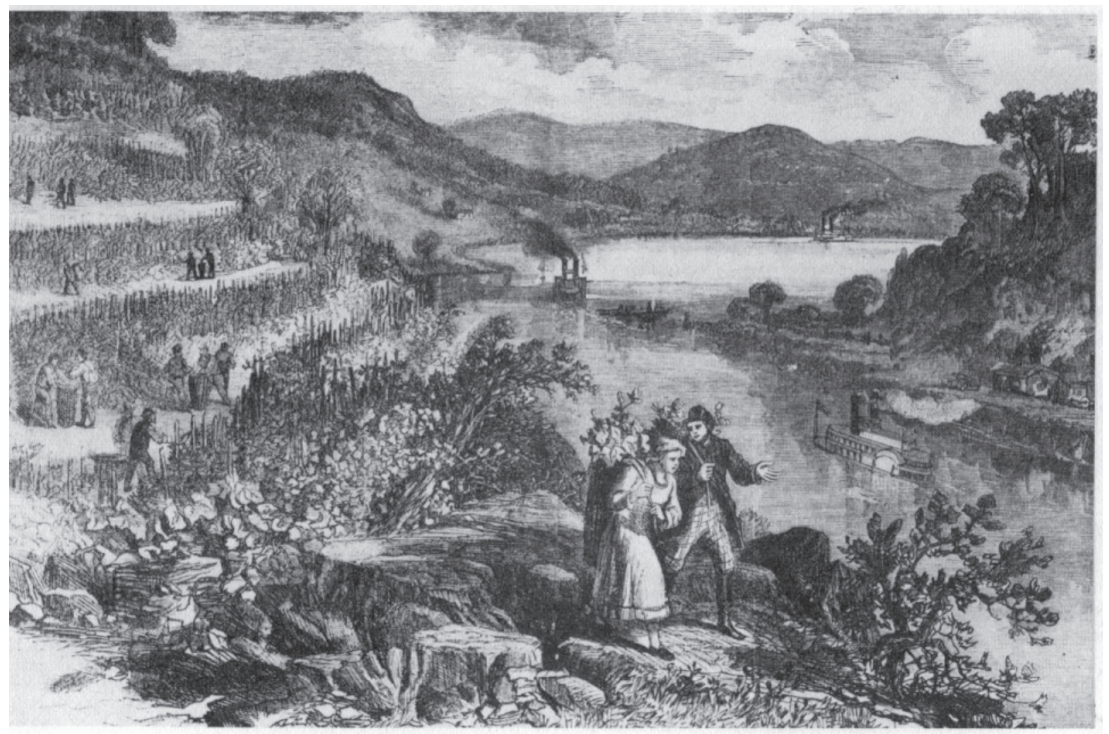

Figure 4: Longworth's vineyards in Cincinnati. Longworth's Wine House, 1866. Courtesy Jed Dannenbaum, Drink and Disorder.

unalienated experience, in its claimed and believed processes of production and consumption. In brief, the logic is this: "great wines come only from fine grape varieties grown in great vineyards, which in turn require great labor and great expense." Thus "great wines" are produced from the world's premiere varietals planted only in ideal locations which add to the grape's taste and the wine's expression of that taste (its terroir). Additionally, "great wines" are produced by highly skilled owner/winemakers who have an intimate knowledge of wine history, wine production, and their own land. ${ }^{41}$ The yeoman farmer dream found within the romance of wine lived on unchecked in the image of the nineteenthcentury vineyard as the quintessential white, elite space, stocked with an ethic of independent natural production, epitomizing power and wealth. Longworth put a fine point on the myth of good wine and genius of elite wine production:

'[A] poor man cannot make good wine.' The reason is obvious. The rich man not only has more influence in obtaining favorable opinions, but he also uses more care and skill in the manufacture. The poor man must sell his wine as soon as made. The rich man retains it till it is improved by age, and never sells under his own name, but that which proves to be of superior quality. ${ }^{42}$

Longworth was aware that as a "rich man," he benefited twice over from his name alone: first in his "influence," essentially the ability to buy "favorable 
opinions" of his wine, and second in his ability to put his name on only the very best wines that his investments produced. Longworth, through surplus capital, stored the wine before selling; he could invest in it but not see a profit from it for years, another crucial factor to the elite wine business.

Longworth did not follow his own ethos or instructions regarding labor in the vineyard. There was no way he could, with hundreds of acres under cultivation. From the beginning, although he did not "hire hands" (i.e., he did not hire white day laborers), he did contract German immigrants as tenants. He described his process:

It has been usual to give a piece of land of say 15 to 20 acres, with a small house on it, to a German vine dresser, on a lease of 12 or 15 years, binding the tenant to put in a certain quantity in grapes each year in a proper manner-and at least five or six acres within as many years, he paying the proprietor onehalf the proceeds of the vineyard annually after bearing. . . . I would recommend landlords to rent from 15 to 20 acres to Germans, for vineyards and orchards, on shares ...; land will be suitable for it, that is too rough for the plough, and eight to ten acres will give employment to a whole family. ${ }^{43}$

Longworth practiced and advocated family farm tenancy for the production of grapes and wine. In his co-authored Treatise on the Cultivation of the Grape, at the end of his description of employing German vinedressers, he promised his land-owning, grape-growing readership that "[t]hose who commence this business, and conduct it properly, will make fortunes by it." ${ }^{\prime 4}$ The focus in the piece was neither grapes nor wine, but instead the profit to be made from German vinedressers' labor.

The immigrant German population in Cincinnati had changed much over the first half of the century. In 1825 there were only about fifty Germans living in the city, and they were relatively well-off. They had been careful to hide their accents and native customs in order to fit in with native-born, or otherwise English-speaking, neighbors. By 1840 however, German immigrants made up almost 30 percent of Cincinnati's population — over 15,000 people — and changed the composition of the working class. The newly arrived Germans, Dreissigern, kept their foreign tongue and habits longer, lived with their own people in their own part of the city, and were generally poorer than earlier immigrants. Their love of drink and tendency to violate the Sabbath made them additionally suspect to the white middle-class population. Germans made up almost 50 percent of the population in 1850. By 1860, there were 2,000 establishments serving alcohol in Cincinnati. ${ }^{45}$ Alienation, antagonism, and all other conditions for constructing an ethnically "other" population were easily met at this moment in Cincinnati.

Longworth capitalized on this. He made regular inspections of his land and tenants' work, describing one visit: 
On the banks of the Ohio, two miles below our city, I yesterday [went to see] some Germans at work, trenching, banking, and walling one of the most steep, rugged, and stony hills in the country. To have hired the work done by the day, would have cost from $\$ 300$ to $\$ 400$ per acre. When completed, it will be a lovely spot. The cost ... is a trifle, for the work is done during winter ... [and] they raise their own hominy and sour crout $[\mathrm{sic}] . . . .[\mathrm{T}]$ he greater part of the work in the vineyard is performed by their wives and daughters, without interfering with household affairs. ${ }^{46}$

Several mid-nineteenth-century processes of ethnic othering are at work here. Longworth economizes by not hiring and paying single laborers, instead employing a method of low-paying farm tenancy, making use of an entire German family's labor. His immigrants are not only industrious but thrifty, raising and eating their own foods. And, unlike mid-century middle-class genteel women, his male tenants' wives and daughters could labor in the vineyard, grow their own food, and continue their work about the house as part of their normal, hard-working, salt-of-the-earth routine. Longworth's ultimate motivation is also clear: the site, "when completed... will be a lovely spot." His attention to the vineyard as an improved aesthetic commodity suggests its value as a tourist site and a future real estate sale. Collectively these examples point to Longworth's grape empire as an example of capitalist expansion through horticultural land speculation - and of the concomitant erasure of economic exploitation through the mythos of neo-yeoman, unalienated, and democratic American wine production.

Longworth's exploitative dealings were registered by the public at the time, mostly in the context of debates over temperance. Through the antebellum years, Cincinnati served as a hotbed of alcohol production and prohibition reform politics. ${ }^{47}$ Conventional wisdom about wine in the nineteenth century was that its effects on the human body were far different from those of hard alcohol: one didn't suffer from "roughness of character" when imbibing wine, nor would wine make a person drunk. Longworth was a long-time advocate of temperance: wine in moderation, rather than prohibition. Moreover, he, like other winegrowers, argued that wine was a good beverage because it was locally grown and "naturally fermented"- only when other elements were added in the distillation process (including sugar or other sweeteners) did alcohol become truly dangerous. ${ }^{48} \mathrm{He}$ placed high importance on the "purity" of his wine over other drinks.

The decades-long battle over prohibition took on a religious as well as class valence in Ohio in Longworth's lifetime. Temperance was a distinctly middleclass issue; a vocal portion of the Jacksonian middle class shunned wine as an aristocratic beverage as well as "demon liquor." Until 1846, Longworth and other elite entrepreneurs" wine circulated almost solely among the highest society and the lowest German immigrant bars of Cincinnati. This made the high and low 
classes unlikely allies against the middle-class push for prohibition, awkward bedfellows in the struggle to keep wine consumption legal. ${ }^{49}$

Due to his substantial wealth and his devotion to temperance, Longworth was known to the proponents of teetotalism as a member of the "wine-drinking aristocracy. ${ }^{" 50} \mathrm{He}$ dug in against advocates of prohibition, tirelessly promoting wine and the wine industry, and battling teetotalers in newspapers and in public debates. One of his arguments was that prohibition would ruin the wine industry and hurt the larger Cincinnati region economically. ${ }^{51} \mathrm{He}$ was, on the surface, correct: prohibition would effectively have put nearly one thousand people in the local wine industry out of work. But laying beneath the surface of his arguments was a consciousness about the way that the city's economy was diversified through its several productive landscapes: Longworth was aware that his investment in viticulture and the land surrounding the city reinforced Cincinnati's image as a national economic and cultural center.

To Longworth's argument that prohibition would harm Cincinnati, Samuel Cary, leader of the prohibition movement, once responded: "We protest against that wealth and splendor which are secured by the miseries, tears and blood of society." ${ }^{2}$ This was a serious charge. One assumes that Cary was describing how the "miseries, tears and blood" caused by the intemperate use of alcohol could befall anyone - "miseries" that the middle-class prohibition lobby fabricated to scare imbibers away from "demon liquor." But read with class status in mind and in light of Longworth's family tenancy system, this was more than political overstatement aimed at the real estate mogul on the hill. The charge is also ironic in light of Longworth's own claim, as well as his biographers' work, which narrate Longworth's supposed democratization of wine. As stated, in the early years, Longworth's flat wines ("hocks") were sold nearly exclusively to taverns serving a poor German immigrant clientele — wines for which the same Germans had grown grapes. Thus Cary had a point when he accused the "aristocracy" of extracting their wealth from the most miserable in society: Germans labored to grow the grapes for Longworth and bought them right back from him as wine. Longworth consistently countered his opposition that only through wine would America be a cultured, civilized country. But his vision of American culture and civilization hardly met its traditional democratic ideal.

\section{Longworth's, and Cincinnati's, Horticultural Empire}

Cincinnati's important sites of capitalist accumulation and ultimate urban transition are nicely encapsulated in the example of Longworth's mid-century wine empire. Cultural geographers and materialist scholars, especially David Harvey, have theorized the paradoxes of urban capitalist development. ${ }^{53} \mathrm{In}$ Cincinnati's case, wine production ran the symbolic "knife-edge path" between capital accumulation and loss, technological advancement and nostalgia-laden links with the past, and Americanization-cum-exploitation of alienated labor. ${ }^{54}$ The wine that Longworth produced was made with the latest technology (also 
highlighted in his tourist literature) but was sold nationally and internationally as symbolizing a pre-industrial past. Moreover, Longworth's wine was localalmost all grapes were fermented into wine within miles of where they were grown - but the vines were not indigenous and for decades the wine bottles needed to be shipped in from the east coast. The vineyards encircling the city acted as a space of both agricultural and urban capitalist accumulation. The formula for capitalist exploitation of the countryside, tied to urban profit, could not be more clearly Cincinnatian. Thirty years later, and two thousand miles west, it would reappear in California.

This process of capitalist urbanization was unwittingly described in the Ohio Farmer in 1867 in a eulogy for Longworth, who died in 1863:
Mr. Longworth has been called away [by God].... The growth of the city demands that very space [Longworth's vineyards] occupy, and another summer may see the excavations preparatory to the erection of splendid houses, where, for thirty years, this persevering vine student trained the canes, and led the tendrils upon his favorite grape trellises. Pioneer of Viticulture in the West, he has nobly opened the way-who will follow it? ?5 $^{55}$

The newspaper eulogizes Longworth as a noble pioneer, his experiments with viticulture wholly different from the "erection of splendid houses" and new growth of Cincinnati. Again, Longworth's pioneering pomological history is identified not as the direct precursor to capitalist urbanization, but as its antithesis. The horticultural land baron was remembered as being concerned only with his fruit, not the immensely valuable land on which it was grown. Longworth masked his fortune in real estate and farm tenancy, and yet he has been memorialized as a neo-yeoman pioneer who democratized wine and brought good health to the West.

The region's identification with its foremost fruit speculator did not wane until long after Longworth's death. By 1860 the prohibition lobby had ceased to be a threat and remained dormant for a few decades thereafter. But throughout the 1850s and 1860s winemakers had a growing, and much bigger problem on their hands: black rot and downy mildew were ravaging vines and destroying as much as three-quarters of the grape crop per year. ${ }^{56}$ California winegrowing, although established in some areas of the state by the mission founders and by Spanish traders, did not take off as a nationally competitive industry until the 1870s. In light of the disease rampaging through the Ohio industry, the focus on and investment in grapes quickly shifted further West. But the later meteoric rise in California's wine trade should not be read as inevitable. It was just as constructed by massive capital investments and just as plagued by boom and bust cycles. Cincinnati continued as an important wine producer and national horticultural area through the 1870 s. 
Thus, Cincinnati and the Ohio region must be added to the national narrative of important horticultural spaces in the nineteenth century. Previous scholars have argued that New York's prominence in all horticultural fields began early in the nineteenth century and continued unabated until 1900, when California took the title of most important horticultural state. ${ }^{57}$ Here, the history of Cincinnati wine production confirms there was a long gestation period for national horticulture in the Midwest, between its inception on the east coast and its fully-fledged lattercentury west coast empire. In each site, horticulturally invested elites offered their region the promise of power, refinement, and the full fruition of nature's wonders. Vineyards functioned as holding spaces for surplus capital, for ennobling and displaying wealth, and for developing other forms of cultural capital. Cincinnati fruit speculation and tourism is thus a crucial addition to a history that has denied the original great west's importance in processes of capitalist urbanization and horticultural production. The extant histories of grape growing — which nearly all celebrate the "great men" of horticulture and focus on the "failure" of American viticulture before it reached California - must be balanced by attention to the persistent capitalist and nationalist thrust of fruit culture in the early Midwest.

\section{Notes}

The author would like to thank the anonymous reviewers and the editors at American Studies, as well as colleagues and friends Laura Rigal, Cynthia Belmont, Megan Threlkeld, Dana Quartana, and David Schildknecht for their comments on this article.

1. Paul Lukacs, a wine columnist and English professor, offers this interesting but problematic history of nineteenth-century American wine in the first two chapters of American Vintage: The Rise of American Wine (Boston: Houghton Mifflin, 2000). Thomas Pinney also has a significant, celebratory section on Longworth in A History of Wine in America: From the Beginnings to Prohibition (Berkeley: University of California Press, 1989). See also Walter Stix Glazer, Cincinnati in 1840: The Social and Functional Organization of an Urban Community during the Pre-Civil War Period (Columbus: Ohio State University Press, 1999), 85-88, and Clara Longworth de Chambrun, The Making of Nicholas Longworth: Annals of an American Family (Freeport, NY: Books for Libraries Press, 1933), as well as her Cincinnati: Story of the Queen City (New York: Charles Scribner's Sons, 1939).

2. Longworth had many appellations, the "father of American wine" being the most popular. His title "the Western Bacchus" is found in C.M., "American Vineyards and Wine," Southern Cultivator 16 (June 1858), 22-23.

3. For example, scholars have scrutinized John Jacob Astor, Cornelius Vanderbilt, and California's "Big Four." Only Gustavus Myers, New York socialist muckraker of the early twentieth century, has compared Longworth with millionaire land barons Astor, Peter Goelet, the Rhinelander brothers, the Schermerhorns (all of New York), and Marshall Field (of Chicago) in his History of the Great American Fortunes (New York: Modern Library, 1910/1936), in "Chapter VIII: Other Land Fortunes Considered."

4. Frieda Knobloch theorizes a later version of Western agricultural imperialism in The Culture of Wilderness: Agriculture as Colonization in the American West (Chapel Hill: University of North Carolina Press, 1996). On the importance of horticulture in America, see also Philip J. Pauly, Fruits and Plains: The Horticultural Transformation of America (Cambridge: Harvard University Press, 2007); Daniel Kevles, "Fruit Nationalism: Horticulture in the United States -From the Revolution to the First Centennial" in Marco Beretta, Karl Grandin, and Svente Lindquist (eds.), Aurora Torealis: Studies in the History of Science and Ideas in Honor of Tore Frangsmyr (Sagamore Beach, MA: Science History Publications, 2008); Cheryl Lyon-Jennes, "Planting a Seed: The Nineteenth-Century Horticultural Boom in America," Business History Review 78 (Autumn 2004); Tamara Plakins Thornton, Cultivating Gentlemen: The Meaning of Country Life Among the Boston Elite, 1785-1860 (New Haven: Yale University Press, 1989). Other fruit entrepreneurs include the William Prince family, "Apple King" Robert Pell, and Ellwanger \& Barry (all of New York), Francis Parkman, Marshall Wilder, and Charles Hovey (of Massachusetts), and others. 
5. Longworth also paid more real estate tax than any other American, save Astor. A short but telling biography of Longworth by Charles Boewe, "Nicholas Longworth," is found in John A. Garraty and Mark C. Carnes (eds.), American National Biography 13 (New York: Oxford University Press, 1999), 898-899. The major text on wine history in America is Pinney's A History of Wine in America. For wine in America in the eighteenth century, see David Hancock, Oceans of Wine: $M a-$ deira and the Emergence of American Trade and Taste (New Haven: Yale University Press, 2009). See also Paul Lukacs, American Vintage; Charles L. Sullivan, Zinfandel: A History of a Grape and Its Wine (Berkeley: University of California Press, 2003); Leon D. Adams, The Wines of America, 3rd ed. (New York: McGraw-Hill, 1985 [1973]). For the fruit industry, see Douglas Cazaux Sackman, Orange Empire: California and the Fruits of /Eden/ (Berkeley: University of California Press, 2005), and Steven Stoll, The Fruits of Natural Advantage: Making the Industrial Countryside in California (Berkeley: University of California Press, 1998).

6. Frieda Knobloch in The Culture of Wilderness details the agricultural colonization of the Midwest, as does Wayne D. Rasmussen (ed.), in Agriculture in the United States: A Documentary History, 4 vols; (New York: Greenwood Press, 1977). See also Booke Hindle and Steven Lubar, Engines of Change: The American Industrial Revolution 1790-1860 (Washington: Smithsonian Institution Press, 1986), 96. In the nineteenth century, federal aid to agriculture increased, as well as money and land for railroads. Percy Wells Bidwell and John I. Falconer's A History of Northern Agriculture, 1620-1840 (New York: Peter Smith, 1941), pages 259, 266, 316, and Siegfried Giedion's Mechanization Takes Command: A Contribution to Anonymous History (New York: Oxford University Press, 1948), 146. Christopher Clark, "The Ohio Country in the Political Economy of Nation Building," in Andrew R. L. Cayton and Stuart D. Hobbes, (eds.), The Center of a Great Empire: The Ohio Country in the Early Republic (Athens: Ohio University Press, 2005), 148.

7. Steven Hahn and Jonathan Prude (eds.), "Introduction" in The Countryside in the Age of Capitalist Transformation: Essays in the Social History of Rural America (Chapel Hill: University of North Carolina Press, 1985), 3. Robert Price, Johnny Appleseed: Man and Myth (Bloomington: Indiana University Press, 1954) 37, 58.

8. Kim M. Gruenwald, River of Enterprise: The Commercial Origins of Regional Identity in the Ohio Valley, 1790-1850 (Bloomington: Indiana University Press, 2002), xi, 157.

9. Andrew R. L. Cayton and Peter S. Onuf (eds.), The Midwest and the Nation: Rethinking the History of an American Region (Bloomington: Indiana University Press, 1990).

10. Charles Cist, in his Sketches and Statistics of Cincinnati in 1851 (Cincinnati: WM. H. Moore \& Co., 1851), 320. In Cincinnati in 1841, Cist predicted that "Within one hundred years ... Cincinnati will be the greatest city in America; and by the year of our Lord two thousand, the greatest city in the world." Charles Cist, Cincinnati in 1841: Its Annals and Future Prospects (Cincinnati: Charles Cist, 1841), 275. Travelers had been writing this for a while: Manasseh Cutler wrote in 1787 that the area between Lake Erie and the Ohio River would be "the garden of the world, the seat of wealth, and the centre of a great Empire." Manasseh Cutler, An Explanation of the Map which Delineates that Part of the Federal Lands . . . (Salem: Dabney and Cushing, 1787), 14. See Cayton and Hobbs, The Center of a Great Empire.

11. Glazer, Cincinnati in 1840, 25, 26. Richard Wade, The Urban Frontier: The Rise of Western Cities, 1790-1830 (Urbana: University of Illinois Press, 1996 [1959]), and D.W. Meinig, The Shaping of America: A Geographical Perspective on 500 Years of History, vol. 2, Continental America, 1800-1867 (New Haven: Yale University Press, 1993), 248.

12. D.W. Meinig, Continental America, 361, 256. Mammoth growth brought St. Louis even with Cincinnati (at about 160,000 people) by 1860 .

13. Jon C. Teaford, Cities of the Heartland: The Rise and Fall of the Industrial Midwest (Bloomington: Indiana University Press), 13. He explains: "As early as 1831 Queen City presses were producing books at the rate of 350,000 volumes annually. Ten years later, estimates of production ranged from one to two million volumes annually."

14. Teaford calls this the development of a "heartland consciousness," Ibid., ix. See also Louis Leonard Tucker, "'Old Nick' Longworth, the Paradoxical Maecenas of Cincinnati," Cincinnati Historical Society Bulletin, 25 (1967), 253. Longworth was always concerned with how Western culture was faring in comparison to Eastern culture, and he financed many artists' trips east for education and exposure to a wider world. Teaford, Cities of the Heartland, 14.

15. The Horticulturist: Journal of Rural Art and Rural Taste, Devoted to Horticulture, Landscape Gardening, Rural Architecture, Botany, Pomology, Entomology, Rural Economy, Etc. (New York: Luther Tucker, 1847-1867).

16. Anonymous, "The Vineyards of Ohio," The Horticulturist (February 1848), 420. It is likely that Downing wrote the article.

17. Nineteenth-century viticulturists were in dialogue with major European wine traditions. See Hancock, Oceans of Wine. For how a nationalist identity was constructed through wine in France, see Kolleen M. Guy, When Champagne Became French: Wine and the Making of a National Identity (Baltimore: Johns Hopkins University Press, 2003).

18. Anonymous, "Horticultural Department. The Vineyards of the West," Ohio Cultivator, October 1, 1850, 300. Reprinted from its previous publication in The Horticulturist. 
19. The Cincinnati Horticultural Society included Longworth, Robert Buchanan, John Mottier, William Resor, C.W. Elliott, A.H. Ernst, and several physicians (Stephen Mosher, Louis Rehfuss, John Aston Warder). Charles Cist, Sketches and Statistics of Cincinnati in 1851, 111, and Cincinnati in 1859, 209. Edward S. Wayne, "Extracts from a Report on the Production of Wine, Brandy, and Tartar, in the Vicinity of Cincinnati," American Journal of Pharmacy XXVII Third Series, Vol. III (Nov. 1855), 494. See also Robert Leslie Jones, History of Agriculture in Ohio to 1880 (Kent: Kent State University Press, 1983), 225, 226. John Frederic von Daacke, “'Sparkling Catawba': Grape Growing and Wine Making in Cincinnati, 1800-1870," (Unpublished MA thesis, University of Cincinnati, 1964), also details the major vineyardists in the area, 53-60, including Kentuckians Dr. Stephen Mosher and B.F. Sanford, and Cincinnatians Thomas Yeatman, Fredric Disserns, Gabriel Sleath, Sebastian Rentz, John Duhme, John Mottier, John Unholtz, George Bogen, Robert Buchanan, John Ross, and Nicholas Longworth.

20. He noted that most of the vineyards were classified as "small," or under three acres. Seventeen were of moderate size (three to five acres), and nine surpassed five acres. Longworth's vineyards spanned 22 acres. Ohio Cultivator, October 15, 1846 and March 15, 1847. See also Douglas Hurt, "The Vineyards of Ohio, 1823-1900," Northwest Ohio Quarterly, 55:1 (1982), 6, and Ellen Corwin Cangi, From Viticulture to American Culture: The History of the Ohio River Valley Meyers Estate, 1845-1965 (n.p. 1983), 10. Robert Jones claims there were more acres under cultivation: there may have been closer to 300 in Hamilton County in 1844, with Longworth owning 80 to 90. See Jones, History of Agriculture in Ohio to 1880, 226. He cites Robert Buchanan's popular Culture of the Grape and the census of 1850 .

21. Nicholas Longworth identifies acreage and a few of his land holdings in his co-authored, with Robert Buchanan, A Treatise on the Cultivation of the Grape, in Vineyards (Cincinnati: Wright, Ferris and Co., 1850): "Number of acres in vineyard culture within a circle of twenty miles around Cincinnati, 743; under charge of 264 proprietors and tenants. Of this, Mr. Longworth owns 122.5 acres, cultivated by 27 tenant [families]" (35-6). He continues, "The oldest vineyard in the county is one of Mr. Longworth's, on Baldface [sic], planted 27 years ago...several other vineyards in this country are from 15 to 18 , and a few 20, years old" (18). In 1846, he said it had been "sixteen years since I bought an unusually broken piece of ground on Boldface Creek, four miles from the city" (34), and the vineyard of his tenant Mr. Rentz was "four miles from town" (35), and his vineyard "at Tusculum, [was] on a high hill" (39).

22. Robert Buchanan, The Culture of the Grape, and Wine-Making (Cincinnati: Moore \& Anderson, 1852), 61

23 DeBow's Review and Industrial Resources_Statistics, etc. Devoted to Commerce, Agriculture, Manufactures (New Orleans: December 1855), 722-3. (The article was also printed in the Ohio Cultivator and New York Journal of Commerce.) The Ohio Cultivator was of course especially interested in spreading the "Rhine of America" designation for Cincinnati. It compared Cincinnati Catawba wine to Rhine wine in 1850: "the Catawba makes . . . a wine so much like the ordinary wines of the Rhine, that we could put three of the former bottles among a dozen of the latter, and it would puzzle the nicest connoisseur to select them either by color or flavor." Anonymous, "The Vineyards of the West," Ohio Cultivator 6 (Oct. 1850), 300-1. Robert Buchanan was also keen to popularize the appellation, discussing it in his book The Culture of the Grape, and Wine-Making. By 1855, the title was assured. See also Cangi, From Viticulture to American Culture, 12-15, and Pinney, A History of Wine in America, 156. The "Rhine of America" also stuck because of the influx of Germans into Ohio (to be discussed).

24. Charles Cist, Cincinnati in 1851; Ohio Cultivator, December 1, 1855, 358; Ohio Farmer, August 7, 1858; U.S. Patent Office Annual Report 1854, Agriculture, 265. See also Hurt, 7-8, and Leon D. Adams, 92. For another Ohio farmer's experiences with grape culture, see A.N. Prentiss, My Vineyard at Lakeview (New York: Lovejoy \& Son, 1866). Prentiss discusses his own experiments with vines, how grape growing was socially and regionally "contagious," and the distribution of Cincinnati's grapes to Chicago, Detroit, and New York.

25. Robert Buchanan, A Treatise on the Cultivation of the Grape, in Vineyards, 27. Grape names typically evoked places the vines were believed to be from, people that had bred them, or (more typical for other ornamental horticultural items) women's names. Longworth's collection in 1846 included the Ohio, Catawba, Graham, Elinburg, Clarkson's Eastern Catawba, Indiana, Black Fox, White Fox, Piqua, Herbemont, Giant Catawba, Minor's Seedling, Norton's Virginia Seedling, White Seedling Catawba, Improved Purple Fox, Red Fox, Virginia, Missouri, Helen, Lake, and Guignard.

26. See Cist, Cincinnati in 1851, 333-338, and "Nicholas Longworth, Esq. of Cincinnati, and the Vineyards of Ohio," Harper's Weekly July 24, 1858, 472. There is some discrepancy in the records of when Longworth arrived. Lukacs and others state that he landed in 1803 (10). Glazer, Cincinnati in 1840 (85), Pinney, A History of Wine in America (157), and Charles Boewe, "Nicholas Longworth" (898) write that it was 1804 . Other sources claim 1810 and later. The 1803 date would have had the most symbolic weight as part of the foundational Longworth myth - it is the year that Ohio was admitted as a state. 
27. Jed Dannenbaum, Drink and Disorder: Temperance Reform in Cincinnati from the Washingtonian Revival to the WCTU (Urbana: University of Illinois Press, 1984), 26, 135. Also see Ohio Writers' Program of the Work Projects Administration, Cincinnati: A Guide to the Queen City and Its Neighbors (Cincinnati: Wiesen-Hart Press, 1943), 43-44. That Longworth was never actually offered the stills makes this narrative profoundly mythical. See Cist, Cincinnati in 1851, 333-338. Pinney, 156-165.

28. Henry Hobhouse argues that grapevines and wine have since the earliest times symbolized stable husbandry, a solid and expanding economic horizon, and security in civilization. Hobhouse, Seeds of Wealth: Five Plants That Made Men Rich (Emeryville, CA: Shoemaker \& Hoard, 2003), 86.

29. Pinney, A History of Wine in America, 156-165, and primary sources previously cited. Earlier in the century, there had been local experiments in grape-growing in Gallipolis, Ohio and Vevay, Indiana, begun in 1796 and 1802 respectively. French inhabitants had attempted to cultivate the Red Fox grape in Gallipolis, while the Swiss Colony at Vevey had tried many grapes, settling on the Cape grape.

30. Ohio Writers' Program, Cincinnati, 44.

31. Glazer, Cincinnati in 1840,87 . The List enumerates 2,559 property owners in the city-only six percent of the city's total population, or less than one-fifth the total adult white male population.

32. The distiller and others called this "waste land," "not worth shucks." DeChambrun, The Making of Nicholas Longworth, 28. Many lots cost \$10 each. Myers, Ch. VIII.

33. Gustavus Myers, History of Great American Fortunes, Chapter VIII. See also Boewe, "Nicholas Longworth," 898.

34. U.S. Patent Office, Annual Report 1845, p. 312. See also Bidwell and Falconer, 381.

35. Nicholas Longworth to Mr. Lytle, House of Representatives, Ohio. March 4, 1852. Cincinnati Historical Society. These numbers are consistent with figures defining a large business, or small industry, in 1850s America. John Frederic Von Daacke, "Sparkling Catawba": Grape Growing and Wine Making in Cincinnati, 1800-1870 (Master's Thesis, University of Cincinnati, 1964), 60. 503.

36. R. B. Buchanan, "Grape Culture and Vineyards," The Cincinnatus 4 (November 1859),

37. Glazer, Cincinnati in 1840, 29. Part of the land that Longworth's vineyards were on is now a portion of Eden Park. Cincinnati Enquirer, December 1, 1853. See also Steven J. Ross, Workers on the Edge: Work, Leisure and Politics in Industrializing Cincinnati, 1788-1890 (Los Angeles: Figueroa Press, 2003 [1985]), 173.

38. Anonymous, "Nicholas Longworth, Esq., of Cincinnati, and the Vineyards of Ohio," Harper's Weekly July 24, 1858, 472-474.

39. On tree stumps, see Barbara S. Groseclose, Nineteenth Century American Art (New York: Oxford University Press, 2000), 135-137, and much criticism of Thomas Cole's series The Course of Empire (1830s), as well as Andrew Melrose's Westward the Star of Empire Takes its Way-Near Council Bluffs, Iowa (1867).

40. Quoted in Buchanan and Longworth, (eds.), A Treatise on the Cultivation of the Grape,

41. John Beeston, A Concise History of Australian Wine (St. Leonards, Australia: Rathdown, 1994), 21. There are hundreds of books over centuries that implicitly belabor this point. For just a few examples, see Hugh Johnson, The World Atlas of Wine (New York: Simon and Schuster, 1977) and H. Warner Allen, A History of Wine: Great Vintage Wines from the Homeric Age to the Present Day (NP, 1961). Julia Flynn Siler, The House of Mondavi: The Rise and Fall of an American Wine Dynasty (New York: Gotham Books, 2007); Mike Weiss, A Very Good Year: The Journey of a California Wine from Vine to Table (New York: Gotham Books, 2005); Michael Sanders, Families of the Vine: Seasons Among the Winemakers of Southwestern France (New York: HarperCollins, 2005), etc.

42. Buchanan and Longworth, A Treatise on the Cultivation of the Grape, 20.

43. Buchanan and Longworth, A Treatise on the Cultivation of the Grape, 28.

44. Ibid., 33.

45. Glazer, Cincinnati in 1840, 57-58, and Teaford, Cities of the Heartland, 9; Ross, Workers on the Edge, 72-73, 172.

46. Buchanan and Longworth, A Treatise on the Cultivation of the Grape, 31-32. Longworth details another story of a German tenant "who had a wife, daughter, and three stout boys" in Culture of the Grape. Longworth contracted them to "trench and wall with stone, six acres for grapes, in three years, and nine acres in five years. He was also to plant out a peach orchard, and tend an apple orchard I had on the place." Buchanan, The Culture of the Grape, and Wine-Making, 56-57.

47. In 1850 Cincinnati was among the top five national producers of whiskey, ale, and wine (Ross, Workers on the Edge, 78). See also Cayton and Onuf (eds.), The Midwest and the Nation.

48. See, for example, a discussion in the Ohio Cultivator, Oct. 1, 1850, 300: “. . the Catawba[s] of this country ... contain so little alcohol (only 7 or 8 per ct,) that they are not intoxicating unless drank in a most inordinate manner ... they exilerate [sic] the spirits, and act in a salutary manner on the respiratory organs." The history of the politics and legality of alcohol in early Ohio is well-told 


\section{Erica Hannickel}

by historians. See Jed Dannenbaum, Drink and Disorder, and Rohrabaugh's The Alcoholic Republic: An American Tradition (New York: Oxford University Press, 1979 [1981]), especially.

49. Ross, Walking on the Edge, 173, 181. Cayton and Onuf(eds.), The Midwest and the Nation, 87-88. For prohibitionists, "demon liquor" included wine.

50. Dannenbaum, Drink and Disorder, 134-5. 1853.

51. Nicholas Longworth, open letter to Samuel Cary, Cincinnati Commercial, August 2, 15,

52. Ibid.

53. See David Harvey, The Urban Experience (Baltimore: Johns Hopkins University Press, 1989 [1985]). See also materialist historians and cultural geographers such as Don Mitchell, The Right to the City: Social Justice and the Fight for Public Space (New York: Guilford Press, 2003), Don Mitchell, The Lie of the Land: Migrant Workers and the California Landscape (Minneapolis: University of Minnesota, 1996), and Alan Kulikoff, The Agrarian Origins of American Capitalism (Charlottesville: University Press of Virginia, 1992).

54. David Harvey theorizes this urban transition: "Capitalist development has therefore to negotiate a knife-edge path between preserving the exchange values of past capital investments in the built environment and destroying... [them] in order to open up fresh room for accumulation. ... [There is] a perpetual struggle in which capital builds a physical landscape appropriate to its own condition at a particular moment in time, only to have to destroy it, usually in the course of a crisis, at a subsequent point in time." Harvey, The Urban Experience, 83.

55. Anonymous, "Longworth's School of Vines," Ohio Farmer Feb. 23, 1867, 59. It was reprinted from Horticultural Annual (date unknown).

56. Jones, History of Agriculture in Ohio to 1880, 227; Pinney, A History of Wine in America, 169-172.

57. Steven Stoll and others have stated that until 1900, when California took the reins, "no state compared to New York in its importance to American horticulture" (Stoll, The Fruits of Natural Advantage, 52-3). He cites Thornton, Cultivating Gentlemen (her book terminates at 1860 and is much more focused on the earlier decades) and Ulysses P. Hedrick, himself a booster for New York horticulture through the 1920 s. 